\title{
EDITORIAL
}

\section{Where Were the Law Schools?}

\section{On Legal Education as Training for Justice and the Rule of Law (Against the 'Dark Sides of Legality')*}

\author{
Iris van Domselaar
}

'Where were the lawyers?' This question has been raised many times and in response to many episodes in modern Western history during which fundamental norms of legality, morality, justice, and humanity were violated. This question has formed part of the attempt to reckon with the monstrosities committed during the Second World War, in which lawyers ${ }^{1}$ - exceptions aside - played an important facilitating role. For instance, in the Dutch context, studies on the functioning of the Supreme Court, the advocacy, and the notary have shed light on their limited ability and willingness to resist Nazi laws and protect those who were most in need of legal protection. ${ }^{2}$ As a former president of the Dutch Supreme Court has put it: 'The Supreme Court has not been able to offer the protection, has not shown the inspiring steadfastness that the Dutch population expected. Looking back, we can only become deeply saddened and overcome with regret about how things went wrong at the time.' ${ }^{3}$

The question of the role played by lawyers has also been addressed in the context of the severe, large-scale wrongs committed during the slavery system in the US ${ }^{4}$ and the apartheid system in South Africa. ${ }^{5}$ Questions have also been raised in reaction

* The author would like to thank her colleagues at the editorial board and two anonymous readers for their valuable comments and suggestions.

1 In this contribution, I will use the term lawyer in a general sense, including all those who practice law, such as attorneys, in-house councils, legal advisors at state departments, and public prosecutors and judges.

2 See Corjo Jansen en Derk Venema, De Hoge Raad en de Tweede Wereldoorlog: Recht en Rechtsbeoefening in de Jaren 1930-1959 (Amsterdam: Boom, 2011); Joggli Meihuizen, Smalle Marges: De Nederlandse Advocatuur in de Tweede Wereldoorlog (Amsterdam: Boom, 2010); Raymund Schütz, Kille Mist: Het Nederlandse Notariaat en de Erfenis van de Oorlog (Amsterdam: Boom, 2016).

3 Speech delivered on 17 November 2011 by Geert Corstens, President of the Dutch Supreme Court, in reaction to the publication of the historical study by Corjo Jansen and Derk Venema on the role of the Supreme Court during the Second World War, https://www.hogeraad.nl/geschiedenis-hogeraad/ (last accessed 15 May 2021).

4 E.g. Robert M. Cover, Justice Accused: Antislavery and the Judicial Process (Yale University Press, 1975\#).

5 E.g. Richard L. Abel, Politics by other Means: Law in the Struggle against Apartheid, 1980-1994 (Abingdon: Routledge, 1995\#). 
to the Watergate scandal ${ }^{6}$ and, more recently, in the wake of the War on Terror under the Bush and Obama administrations. ${ }^{7}$ In addition, dozens of articles have criticized the role of lawyers during many corporate and financial frauds that have occurred in the US, such as the Enron bankruptcy scandal, and, more recently, the General Motors' ignition switch scandal and the Volkswagen emissions fraud scandals. ${ }^{8}$ In the financial, transactional context, the question 'Where were the lawyers?' was famously articulated in a ruling by judge Spotkin in the Lincoln Savings Case: 'Where were these professionals ... when these clearly improper actions were being consummated? ... Why didn't any of them speak up or disassociate themselves from the transactions?' ${ }^{9}$

A relatively new chapter in the morally ambivalent track record of lawyers in upholding the rule of law and ideals of justice has been added by the rise of undemocratic regimes on both sides of the Atlantic, with their legal systems that have been described as 'abusive constitutionalism', ${ }^{10}$ 'rule of law backsliding', ${ }^{11}$ 'autocratic legalism', ${ }^{12}$ or 'stealth authoritarianism'. ${ }^{13}$ Lawyers in these systems have been subjected to severe criticism: For instance, former president Trump's personal (election) lawyers ${ }^{14}$ and the legal advisers to the Trump administration have been criticized for giving priority to their personal loyalty to the president, instead of the rule of law and justice. ${ }^{15}$ However, lawyers in these systems have also been praised: For example, Turkish lawyers such as Selçuk Kozağaçlı, and Polish judges Małgorzata Gersdorf and Igor Toleya, have been held up as exemplars of coura-

6 E.g. Mark Hansen, '1965-1974: Watergate and the Rise of Legal Ethics', ABA Journal (2015), https://www.abajournal.com/magazine/article/1965_1974_watergate_and_the_rise_of_legal_ ethics; Arnold Rochvarg, 'Enron, Watergate and the Regulation of the Legal Profession', Washburn Law Journal 43 (2003): 61.

7 E.g. Richard L. Abel, Law's Wars: The Fate of the Rule of Law in the US 'War on Terror' (Cambridge University Press, 2018); Richard L. Abel, Law's Trials: The Performance of Legal Institutions in the US 'War on Terror' (Cambridge: Cambridge University Press, 2018); David Cole, The Torture Memos: Rationalizing the Unthinkable (The New Press, 2009); David Luban, Torture, Power and Law (Cambridge: Cambridge University Press, 2014).

8 E.g. Robert W. Gordon, 'A New Role for Lawyers?: The Corporate Counselor after Enron', Connecticut Law Review 35 (2003): 1185-1216; Michele Benedetto Neitz, 'Where were the lawyers?: The Ethical Implications of the General Motors Recall Scandal in the United States', Legal Ethics 18 (2015): 93-96; Daniel Jacobs, 'The Volkswagen Diesel Emissions Scandal and Accountability: Where Were the Auditors and Attorneys during the Sustainability Charade?', The CPA Journal, July 2019, https://www.cpajournal.com/2019/07/22/9187/ (last accessed 15 May 2021).

9 Lincoln Sav. \& Loan Ass'n v. Wall, 743 F. Supp. 901, 920 (D.D.C. 1990).

10 David Landau, 'Abusive Constitutionalism', UC Davis Law Review 47 (2013): 189-260.

11 Laurent Pech and Kim L. Scheppele, 'Illiberalism Within: Rule of Law Backsliding in the EU', Cambridge Yearbook of European Legal Studies 19 (2017): 3-47.

12 Kim L. Scheppele, 'Autocratic Legalism', The University of Chicago Law Review 85 (2018): 545-584 .

13 Ozan O. Varol, 'Stealth Authoritarianism', Iowa Law Review 100 (2015): 1673-1742.

14 For a critique of Trump's election lawyers, see Michael Hiltzik, 'Trump's Election Lawyers Should Be Disbarred', Los Angeles Times, December 2014, https://www.latimes.com/business/ story/2020-12-14/trumps-election-lawyers-should-be-disbarred/ (last accessed 15 May 2021).

15 See, for instance, for a critique of the Attorney General at the US Department of Justice working under Trump: Maggie Jo Buchanan, 'Attorney General William Barr Is Willing to Destroy the Rule of Law for the Trump Administration,' Center for American Progress, 2 June 2020, https://www. americanprogress.org/issues/democracy/news/2020/06/02/485702/attorney-general-williambarr-willing-destroy-rule-law-trump-administration/ (last accessed 15 May 2021). 
geous lawyers and judges who, despite severe personal and professional risk, continued to serve ideals of justice and the rule of law. ${ }^{16}$ In the words of Toleya: '[I]t is not just our right as judges to speak up when the rule of law is being threatened, it is also our duty ... I've had to face harsh consequences because of my rulings. I have survived them all and I now feel free to speak my mind. ${ }^{17}$

A highly dilemmatic picture of the 'lived experience' of the life of a lawyer working within an authoritarian regime was recently provided by Erica Newland. In December 2020, she wrote a penetrating op-ed in the New York Times with the title: 'I'm Haunted by What I Did as a Lawyer in the Trump Justice Department.' Newland had started as a public lawyer under the Obama administration but decided to stay on the job to serve the Trump administration. As she put it: 'I believed I could better serve our country by pushing back from within than by keeping my hands clean. ${ }^{18}$ However, she changed her mind: 'No matter how much any one of us pushed back from within, we did so as members of a professional class of government lawyers who enabled an assault on our democracy - an assault that nearly ended it. We owe the country our honesty about that and about what we saw. We owe apologies. I offer mine here. ${ }^{\prime 19}$

It is precisely this type of dilemma that David Luban addresses in his article 'Complicity and Lesser Evils: A Tale on Two Lawyers', which will appear in a symposium with several comments in the Georgetown Journal of Legal Ethics. ${ }^{20}$ The central question Luban raises is: '[W] hen a regime comes to power that does awful things, or tries to, or threatens to, how should decent people in the government respond?'21 Should they stay or quit? In this article, Luban's central interlocutor is Hannah Arendt because of her categorical rejection of the strategy of 'lesser evilism'- that is, the choice to stay on the job, as she put it, 'in order to prevent worse things from

16 See for a discussion of courage as a judicial virtue also: Iris van Domselaar, 'Moral Quality in Adjudication: On Judicial Virtues and Civic Friendship', Netherlands Journal of Legal Philosophy 44 (2015): 31-32. See for a more general discussion of the virtue of courage for legal professionals: Marc Loth, 'De Goede Jurist: Over Morele Moed, Onafhankelijkheid en een Riskante Omgeving', in Code en Karakter: Beroepsethiek in Onderwijs, Jeugdzorg en Recht, ed. by Jos Kole and Doret de Ruyter, (Amsterdam: SWP Uitgeverij, 2009).

17 'In Poland a Stubborn Defender of Judicial Independence' (The Saturday Profile), New York Times, 11 January 2020, https://www.nytimes.com/2020/01/10/world/europe/poland-judges-tuleya. html (last accessed 15 May 2020).

18 Erica Newland, 'I'm Haunted by What I Did as a Lawyer in the Trump Justice Department' (op-ed), New York Times, 20 December 2020, https://www.nytimes.com/2020/12/20/opinion/trumpjustice-department-lawyer.html (last accessed 15 May 2021).

19 Ibid.

20 The comments of this symposium are provided by Leora Bilsky and Natalie Davidson, Kathleen Clark, Erica Newland, and Shannon Prince. At the time of writing, only Bilsky and Davidson's comment has been pre-published on SSRN. See Leora Bilsky and Natalie R. Davidson, 'Legal Ethics in Authoritarian Legality', Georgetown Journal of Legal Ethics (forthcoming), https://papers.ssrn. com/sol3/papers.cfm?abstract_id=3778546 (last accessed 15 May 2021).

21 David Luban, 'Complicity and Lesser Evils: A Tale of Two Lawyers', Georgetown Journal of Legal Ethics (forthcoming), https://papers.ssrn.com/sol3/papers.cfm?abstract_id=3817495 (last accessed 15 May 2021). 
happening' ${ }^{22}$ For Arendt, this strategy necessarily leads to self-deception and contributes to a collective moral breakdown: '[T] hose who choose the lesser evil forget very quickly that they chose evil. ${ }^{23}$

Luban develops his argument by presenting and evaluating two moral biographies - those of Bernhard Lösener and of Count Helmuth James von Moltke, both practicing lawyers during the Third Reich. ${ }^{24}$ As Luban put it: 'Both might well stake claims to accomplishing lesser evils ... Yet either or both might have been fooling themselves, as Arendt seems to have thought.' ${ }^{25}$

Drawing on these two moral biographies, as well also on Lepara and Goodin's On Complicity, ${ }^{26}$ Luban argues against Arendt that, under certain conditions, lawyers are justified in staying on the job. Luban avoids promulgating a strict consequentialist approach, which, in this specific context, would arguably boil down to an exclusive focus on the expected lives that would be saved by staying. A broader assessment of the way to approach this dilemma is needed. According to Luban, 'character matters, motives matter, moral vision matters, self-honesty and self-deception matter, the day-to-day texture of life matters, complicity matters'. ${ }^{27}$

In providing this broader framework, Luban lists several factors that should be taken into account, such as the expected effect of quitting in protest, the extent to which one's moral vision is likely to become corrupted by staying, or the extent to which staying on the job contributes to the moral breakdown of those in one's professional surrounding. ${ }^{28}$ In addition, he describes certain conditions under which the strategy of 'lesser evilism' will be more likely to succeed - such as having sufficient 'oppositional maneuvering room' (Spielraum) - and not falling prey to the 'effectiveness trap.'29 Luban summarizes his view on the matter as follows: 'Sometimes quitting is the right thing to do; but when there is Spielraum, and a genuine prospect of mitigating evil, staying at the desk can be the righteous path. But only for those who actually resist. This is a lesson that matters today as well as yesterday, and in other regimes other than dictatorships. ${ }^{30}$

With this approach, Luban aims to offer a more realistic explanatory and evaluative framework for legal professionals such as Newland, Gersdorf, and many others, ed.), Responsibility and Judgment, (New York: Schocken 2003), 34.

23 Ibid., 36. This was one lesson that she drew from the fact that during the Third Reich 'there were very few people who [..] wholeheartedly agreed with the late crimes of the regime and a great number who were perfectly willing to commit them nevertheless'. Ibid., 35.

24 Due to the limited scope of this contribution, I will not go into these rich and illuminating moral biographies themselves, although they are, of course, in and of themselves worthy of further attention and discussion.

25 David Luban, 'Complicity and Lesser Evils', 11.

26 Chiara Lepora and Robert E. Goodin, On Complicity and Compromise (Oxford: Oxford University Press, 2013).

27 David Luban, 'Complicity and Lesser Evils', 46.

28 Ibid., 53.

29 By this Luban means 'the urge to hold your fire until something more important comes'. Ibid., 50.

30 Ibid., 53. 
each of whom stay(ed) on their job within an illiberal regime. ${ }^{31}$ However, as Luban himself also suggests, this framework is not exclusively relevant for illiberal regimes. It is potentially of use in any situation in which conscientious lawyers play a role in an organization or institution through which, either directly or indirectly, basic norms of justice, morality, and democracy are violated other than by means of a tragic incident or incidental mistake. Conscientious lawyers who are committed to ideals of justice and the rule of law do not need to live within an illiberal regime to face situations that give rise to the question of whether it is justified to stay in one's job.

The broader relevance of Luban's framework is well illustrated by the Dutch childcare benefits scandal, a recent episode of 'unprecedented injustice', ${ }^{32}$ which in January 2021 led to the dismissal of the Dutch cabinet. The scandal involved about 30,000 parents who were confronted with discriminatory and extremely severe recovery actions by the Dutch tax authority. Brenninkmeijer and Bish summarize the practice as follows: 'If proof of payment [to the child care organisation] of, for instance, $€ 100$ was missing, the full sum of the benefits already awarded was reclaimed. In most cases, this was between 10 to 20 thousand euros. And the authority did not accept any delay in payment [..]. This caused complex problems for many families and often resulted in a loss of employment, divorce, or highly uncomfortable family relations, since parents had to borrow huge amounts of money from their relatives. ${ }^{33}$

Indeed, one of the many questions being raised in Dutch legal journals in response to the scandal is 'Where were the lawyers?'- for example, the judges and the lawyers working at the tax authority and at the governmental departments, but also the legal scholars specialized in tax and administrative law. It is now generally accepted that - except for a few individual lawyers - in general the legal profession fell short in preventing the occurrence of these large-scale injustices. ${ }^{34}$ As a journal-

31 More realistic because, in the end, as Luban has put it,'unfortunately very few will go home'; Ibid., 53.

32 This is the title of the report that the parliamentary committee of inquiry issued on the child care benefit system. See: Parlementaire ondervragingscommissie Kinderopvangtoeslag, 'Ongekend Onrecht', 2020, https://www.tweedekamer.nl/sites/default/files/atoms/files/20201217_ eindverslag_parlementaire_ondervragingscommissie_kinderopvangtoeslag.pdf (last accessed 15 May 2021).

33 Alex Brenninkmeijer and Didel Bish, 'Professional Ethics for Judges: Lessons Learned from the Past Moral Leadership for Judges Beyond Codes of Conduct', Law and Method (forthcoming). As to the consequences, one of the victims, Kristie Rongen, put it as follows: 'My total debt was $€ 92,000$, I went into a debt relief programme, was called a fraudster. I was isolated, I didn't work for two years, I had to have psychiatric help and my youngest daughter threatened to commit suicide', she says. 'Sometimes I had to send my children to bed with just bread and butter just to have something in their stomachs because we had no more food. I was almost thrown out of my house, but my employer paid my rent.' https://www.dutchnews.nl/news/2021/01/the-childcare-benefitsscandal-voices-of-the-victims/.

34 Such as Eva González Pérez, who represented many of the victims, the administrative judges of the district court of Rotterdam, and Sandra Palmen-Schlange, who worked as a senior lawyer at the tax authority and wrote a highly critical internal report about the unlawfulness of the policies that were pursued. 
ist put it: 'Anyone who oversees the battlefield of the benefits affair must conclude that there were few heroes. ${ }^{35}$ As to the functioning of the highest general administrative court, responsible for reviewing the lawfulness of the decisions of the tax authority and the lower courts, the parliamentary committee stated the following: '[The court] has ... neglected its important function of (legal) protection of individual citizens. ${ }^{36}$

If we apply Luban's framework to the decade during which these injustices occurred, several normative and factual questions and perspectives naturally arise. To what extent did the individual lawyers who were in one way or another involved experience any Spielraum in their direct professional surrounding to mitigate the harsh policies, laws, and precedents, and how exactly did they use and perhaps even create this Spielraum? And if they did not experience any such Spielraum and could not create it, to what extent did they grapple with the dilemma of staying or quitting? ${ }^{37}$ Have they thought about quitting in protest as a way to shed light on the injustices that occurred? Were the judges aware that their judgments could possibly lead to what Luban (after Arendt) describes as a 'moral breakdown' among all the lawyers involved? ${ }^{38}$ And to what extent did those lawyers who were involved perhaps fall prey to the 'effectiveness trap', that is, did they want to save their energies and their moral capital for more 'important' cases that were still to come? ${ }^{39}$

Sure, one straightforward and dismissive general response to all of these questions might be: It was the legal system that was at fault! How can you focus on the functioning of individual lawyers while ignoring the fact that these injustices were to a

35 Jesse Frederik, 'Lessen uit de Toeslagenaffaire', Nederlands Tijdschrift voor Bestuursrecht 64 (3) (2021).

36 'Ongekend Onrecht', 7.

37 Palmen-Schlange, the senior lawyer at the tax authority, did indeed decide to quit her job after her critical report was ignored by her superiors and colleagues and after she was offered another function, which, if she had accepted it, would have entailed her losing her position of independence. See: 'De afdeling Toeslagen zette de ambtenaar die "stop!" riep op een zijspoor', Trouw, 17 November 2020, https://www.trouw.nl/binnenland/de-afdeling-toeslagen-zette-de-ambtenaar-die-stopriep-op-een-zijspoor $\sim$ bed2f08b/?utm_campaign=shared_earned\&utm_medium=social\&utm_ source=copylink (last accessed 15 May 2021).

38 One legal scholar in this context for instance observes that 'the courts [..] have attempted to move [the highest general administrative court] to a more citizen-friendly approach, but have ultimately allowed themselves to be “ocialized”.' Leo Damen, 'Lessen uit de Toeslagenaffaire', Nederlands Tijdschrift voor Bestuursrecht 63(3) (2021).

39 Perhaps an instance of this 'effectiveness trap' can be read in one of the explanations that the president of the highest general administrative court gave for why the court had waited so long in changing course as to the interpretation of the applicable laws. As he put it: 'the court had to wait and search for a suitable case by means of which the change of course could take effect.' Bart Jan van Ettekoven, 'Tussen Wet en Recht: Reactie van de Voorzitter van de Afdeling Bestuursrechtspraak van de Raad van State op het Rapport "Ongekend Onrecht van de Parlementaire Ondervragingscommissie Kinderopvangtoeslag', Nederlands Juristenblad 2”(2021): 101. 
large degree the result of structural features of Dutch administrative law ${ }^{40}$ What do you expect from a lawyer working at the tax authority if the parliament itself has passed these laws, fully consonant with the 'law and order' policies for the prevention of social benefit fraud, which the Dutch government had committed itself to? What can you expect from judges working at a district court who are committed to values such as consistency and coherence if the highest court rules that the practice in question is in accord with the law? What do you expect from judges and legal officers working in administrative law - an area of law that, in the Netherlands, due to several factors allows little leeway to mitigate the potential harsh and disproportional consequences of the application of a formal law to a concrete case? ${ }^{41}$

Such questions reflect Bilsky and Davidson's critical comments on Luban's article. ${ }^{42}$ They charge Luban for promulgating too agentistic an approach to the dilemma. ${ }^{43}$ According to Bilsky and Davidson, Luban focuses excessively on the individual agent and the factual Spielraum in their personal professional surroundings while paying insufficient attention to the complex interplay between the agent and the system. An agentist approach, or so they state, 'obscures from view the broader set of constraints and possibilities within which actors operate, ex-ante, under conditions of uncertainty. ${ }^{\prime 4}$ In adequately accounting for the dilemmas of lawyers within a legal system due attention should be paid to the specific features of that legal system.

As part of a more integrative approach to the dilemma's faced by lawyers within illiberal regimes, Bilsky and Davidson highlight for instance the fact that, while 'legality is a powerful tool of authoritarianism', it also 'produces tools of resistance in the form of legal proceedings, institutions, and discourse'. ${ }^{45}$ Therefore, lawyers working within such regimes face a specific dilemma: by using these 'tools of resistance' they may well mitigate harm - and perhaps discover avenues to reform the system from within - but they also run the risk of 'strengthen[ing] the regime in the long term, by legitimizing it and solidifying its control over the general population'. ${ }^{46}$ Moreover, by staying on the job, such lawyers also risk 'losing the faculty to

40 Brenninkmeijer and Bish summarize this system failure as follows: "The origin of this system failure was the inadequate functioning of feedback mechanisms, the ignoring and distorting of feedback signals, or an inadequate response to those signals. [..] Failure in the trias politica resulted in the misunderstanding and violation of the general principles of good governance.' Alex Brenninkmeijer and Didel Bish, 'Professional Ethics for Judges', 12. See also Sjoerd Zijlstra, 'Lessen uit de Toeslagenaffaire', Nederlands Tijdschrift voor Bestuursrecht 60(3) (2021).

41 This last point seems to be suggested by the president of the highest administrative court who openly responded to the critical report of the parliamentary committee by acknowledging that indeed the court "could have contributed earlier to the necessary correction of "system failure" of the legislator and of the implementation'. But he also stressed that the parliamentary committee had not fully acknowledged the specific dilemma that the court had faced due to specific features of Dutch administrative law. Bart Jan van Ettekoven, 'Tussen Wet en Recht', 101.

42 Leora Bilsky and Natalie R. Davidson, 'Legal Ethics in Authoritarian Legality'.

43 In view of the limited scope of this contribution, I will not delve into the question to what extent Luban's approach can indeed be rightfully qualified as an agentist approach.

44 Leora Bilsky and Natalie R. Davidson, 'Legal Ethics in Authoritarian Legality', 6.

45 Ibid., 9.

46 Ibid., 10. 
identify injustice when it is before you, and thus to find oneself eventually participating in perpetuating such injustice'. ${ }^{47}$

Of course, this point is not only relevant for illiberal regimes. In liberal legal systems, too, legality can de facto allow for, facilitate, neutralize, and legitimize a vast range of injustices. As Cover has famously put it: '[L]egal interpretation takes place in the field of death and pain. ${ }^{48}$ Moreover, in liberal legal orders legality allows lawyers to confront the pain and tragic predicaments that citizens or non-citizens suffer due to the law 'as dispassionately as we view the April showers that bring the flowers of May'. ${ }^{49}$ So conceived, another question that could be addressed in the context of the childcare benefits scandal would be: To what extent were the lawyers involved aware of the potential distortive effect of the legal discourse they used, with its 'neutral' legal distinctions and concepts such as 'fraud'50 and 'mandatory law', on their moral vision of the harm inflicted?

'Where were the lawyers?' This question is often used to assign and discuss issues of professional responsibility post hoc. Equally important, of course, is the ex-ante role of legal ethics and the contribution it can make to avoid similar injustices to occur in the future. One such way would be to better prepare future lawyers for the pressing dilemmas they will face. Indeed, as is well known, the Watergate affair led to a compulsory legal ethics course at each and every law school in the United States. ${ }^{51}$ Presently, at Dutch law schools hardly any work is done in the area of legal ethics and the professional responsibilities of individual lawyers. Hence, in response to the Dutch childcare benefits scandal, we could also add to the long list of questions: Where were the law schools ${ }^{52}$

Bilsky and Davidson in any case hope that the symposium on Luban's 'Complicity and Lesser Evils' will spur debate on the role of legal education in preparing lawyers to fully face the tough dilemma's they will face. They stress that for this purpose legal education should not only 'emphasize the normative ideals and promise of

47 Ibid., 11.

48 Robert Cover, 'Violence and the Word', Yale Law Journal 95 (1985): 1601-1629.

49 Louis Wolcher, Law's Task: The Tragic Circle of Law, Justice and Human Suffering (Applied Legal Philosophy: Ashgate, 2008), 62.

50 See Reinier van Zutphen, 'Woorden zijn nooit zonder betekenis en daden trouwens ook niet', , Nederlands Tijdschrift voor Bestuursrecht 74(3) (2021).

51 Of course, this prompted a range of cynical reactions, nicely phrased by Kathleen Clark, expressing her gut reaction: 'Did the ABA really believe that if only G. Gordon Liddy had been given instruction in legal ethics, he never would have planned the break-in of the Democratic National Committee headquarters in the Watergate?' (Clarke, however, does argue that legal ethics courses can have a positive effect on legal practice.) Kathleen Clark, 'The Legacy of Watergate for Legal Ethics Instruction', Hastings Law Journal 51 (2000): 673.

52 See for the potential lessons of the Dutch childcare scandal for respectively law schools and vocational training for lawyers also: Jacobine van den Brink and Rolf Ortlep, 'Kinderopvangtoeslagaffaire: De Democratische Rechtsstaat Wordt als Staal in de Wind Gehard', Nederlands Juristenblad 5 (2021): 353-370; Alex Brenninkmeijer and Didel Bish, 'Professional Ethics for Judges'. 
the rule of law, it should also include historical examples and theoretical tools that allow for a better understanding of the "dark sides of legalism". ${ }^{53}$

It is of course in and by itself an important empirical question to what extent it is feasible to expect from future lawyers to take moral reasons into account when deciding whether to join, for instance, the judiciary, a big or small law firm, an $\mathrm{NGO}$, an international public organization, the local or national government, an administrative agency, or the office of the public prosecutor, and whether to stay or quit once employed. ${ }^{54}$ The influence of income, status, and the expectations of significant others may turn out to be decisive for the majority of lawyers when deciding what to do in case they are confronted with the violation of norms of justice and the rule of law. In addition, in view of all the empirical research on our general human tendency to rationalize our behaviour in the moral domain, the difference between self-interested reasons and moral reasons will at least for the individual lawyer often be difficult to tell. ${ }^{55}$ Hence, as Nicolson and Webb have put it: 'It is [...] essential that aspiring lawyers are aware of these dilemmas and constraints before they make career choices and that they are encouraged to consider such choices in terms of their moral implications rather than simply in terms of financial rewards, career prospects and job satisfaction'. ${ }^{56}$

As part of a realistic didactic law schools could in any case confront students with the many ways in which legalism - the range of instruments, institutions, and discursive resources provided by a legal system - can be used and how it functions. They could learn students the many ways in which Wendel is right when stating that 'the law is neither inherently good nor inherently bad but is instead a tool that can be used for good or bad ends'. ${ }^{57}$ In this way, they could help students to endure ambivalence regarding the moral merits of the legal order they will likely be part of and avoid offering students an exclusively cheerful and (self)complacent story about the law, legal practice, and the role of legal professionals therein. ${ }^{58}$ Law schools could also prevent students from too easily relying on the justificatory force of legal and professional concepts when it comes to their own potential contributions to the suffering of others. Law students could be trained to be critical of

53 Leora Bilsky and Natalie R. Davidson, 'Legal Ethics in Authoritarian Legality', 9. Bilsky and Davidson drew inspiration for the use of this term from David Kennedy's The Dark Side of Virtue: Reassessing International Humanitarianism (Princeton: Princeton University Press, 2004).

54 As to the first question, whether to join a particular legal practice, Webb and Nicolson state that 'this is perhaps the most significant ethical decision in a lawyer's career'. David Nicolson and Julian Webb, Professional Legal Ethics: Critical Interrogations (Oxford: Oxford University Press 2000), 283.

55 See, for instance, David Luban, 'Integrity. Its Causes and Cures', Fordham Law Review 72 (2003): 279-310.

56 David Nicolson and Julian Webb, Professional Legal Ethics, 283.

57 Bradley Wendel, Ethics and Law: An Introduction, (Cambridge: Cambridge University Press, 2014), vii.

58 Judith Resnik, 'Ambivalence: The Resiliency of Legal Culture in the United States', Stanford Law Review 45 (1993): 1525. See Iris van Domselaar, 'Law's Regret: On Moral Remainders and a Virtue-Ethical Approach to Legal Decision-Making', available at SSRN: https://ssrn.com/ abstract=3604048 (last accessed 15 May 2021), 40. 
the use of abstract legal and professional concepts as 'magic solving words', ${ }^{59}$ which often raise more questions than they answer.

Ultimately, law schools could provide a space where the stories of the victims of legality and those of the legal professionals involved are heard and where tough questions can be raised in response.

59 See F.S. Cohen, 'Transcendental Nonsense and the Functional Approach', ETC. A Review of General Semantics 82(2) (1944): 91. For a critique on the use of a superficial, complacent use of normative concepts in the context of legal ethics: D. Luban, 'Fiduciary Legal Ethics, Zeal, and Moral Activism', Georgetown Journal of Legal Ethics 33 (2020): 298-300. 